\title{
Low temperature method for the production of calcium phosphate
} fillers

\author{
Anna Rita Calafiori ${ }^{1}$, Marcello Marotta ${ }^{2}$, Alfonso Nastro $^{3}$ and \\ Guglielmo Martino*1
}

\author{
Address: ${ }^{1}$ Department of Cell Biology, University of Calabria, ${ }^{2}$ Department of Experimental and Clinical Medicine, Federico II Polyclinic, \\ University of Naples, Italy and ${ }^{3}$ Department of Territory Planning, University of Calabria, Italy \\ Email: Anna Rita Calafiori - calafiori@unical.it; Marcello Marotta - marmarot@unina.it; Alfonso Nastro - a.nastro@unical.it; \\ Guglielmo Martino* - martino@unical.it \\ * Corresponding author
}

This article is available from: http://www.biomedical-engineering-online.com/content/3/I/8

(C) 2004 Calafiori et al; licensee BioMed Central Ltd. This is an Open Access article: verbatim copying and redistribution of this article are permitted in all media for any purpose, provided this notice is preserved along with the article's original URL.

\begin{abstract}
Background: Calcium phosphate manufactured samples, prepared with hydroxyapatite, are used as either spacers or fillers in orthopedic surgery, but these implants have never been used under conditions of mechanical stress. Similar conditions also apply with cements. Many authors have postulated that cements are a useful substitute material when implanted in vivo. The aim of this research is to develop a low cristalline material similar to bone in porosity and cristallinity.
\end{abstract}

Methods: Commercial hydroxyapatite (HAp) and monetite (M) powders are mixed with water and compacted to produce cylindrical samples. The material is processed at a temperature of $37-$ 120 degrees $C$ in saturated steam to obtain samples that are osteoconductive. The samples are studied by X-ray powder diffraction (XRD), Vickers hardness test (HV), scanning electron microscopy (SEM), and porosity evaluation.

Results: The X-ray diffractions of powders from the samples show patterns typical of HAp and $M$ powders. After thermal treatment, no new crystal phase is formed and no increase of the relative intensity of the peaks is obtained. Vicker hardness data do not show any relationship with treatment temperature. The total porosity decreases by $50-60 \%$ according to the specific thermal treatment. Scanning electron microscopy of the surfaces of the samples with either HAp $80 \%-M$ $20 \%$ (c) or Hap 50\%-M 50\% (f), show cohesion of the powder grains.

Conclusions: The dissolution-reprecipitation process is more intesive in manufactured samples (c) and (f), according to Vickers hardness data. The process occurs in a steam saturated environment between 37 degrees and 120 degrees C. (c) (f) manufactured samples show pore dimension distributions useful to cellular repopulation in living tissues.

\section{Background}

From about 1990, calcium phosphate manufactured samples, typically produced with hydroxyapatite, are used as spacers or fillers in orthopedic reconstruction and as fillers in maxillofacial applications, [1-10], however, these implants have never been used under mechanical stress. Also, cements have been increasingly employed in craniofacial trauma surgery and dentistry [11-14], and after time these implants are reabsorbed and replaced by newly formed mineralized matrix. 
At present many researchers prefer to produce macroporous ceramics, which are biologically compatible and show osteoinductive properties $[15,16]$. That is when they are implanted in vivo in ectopic areas, new mineral bone matrix is detectable after only six months.

If porous ceramics are prepared with organic matrices, such as collagen type I $[17,18]$, and bone marrow cells $[19,20]$, they show osteogenic activity even if implanted in bone tissue and ectopic areas of experimental animals and in vitro cultures.

The cements are obtained from powders mixed in water and hardened for a short time at $37^{\circ} \mathrm{C}[21,22]$. The preferred phosphates are monetite $\left(\mathrm{CaHPO}_{4}\right)$ and brushite $\left(\mathrm{CaHPO}_{4} \cdot 2 \mathrm{H}_{2} \mathrm{O}\right)$ [22-25]. These products give hydroxyapatite precipitates, so the cements harden and often are suggested as repair materials in those regions that are not under mechanical stress.

Many authors postulate that such compounds are useful as substitute materials when implanted in vivo. The replacement of these materials by ex novo formed bone occurs by a combination of osteoconduction and implant resorption [12-14].

The aim of the present research is to obtain low crystalline materials similar to bone in porosity and cristallinity. Our manufactured samples are characterized by X-ray powder diffraction (XRD), scanning electron microscopy (SEM), Vickers hardness test (HV) determination, porosity evaluation and calcium solubility of the powders used to produce the fillers.

The data obtained are extremely useful in evaluating the chemico-physical properties of manufactured samples and should be extremely useful in interpreting the morphological and X-ray diffraction data. The relationships among these data could help facilitate production of the fillers that we have studied.

\section{Methods}

Hydroxyapatite $\left(\mathrm{Ca}_{10}\left(\mathrm{PO}_{4}\right)_{6}(\mathrm{OH})_{2}\right)$, (HAp) and monetite $\left(\mathrm{CaHPO}_{4}\right),(\mathrm{M})$ from Aldrich (Sheboygan, WI, USA) are used to prepare manufactured samples. Both powders are mechanically mixed for one minute, then the powders are wetted with distilled water and milled by a hand operated pestle for one minute more. The cylindrical specimens $(1.27 \mathrm{~cm} \mathrm{D}, 6 \mathrm{~mm} \mathrm{H})$ are enclosed in a steam saturated atmosphere at one of the following temperatures $37,60,80,100$, and $120^{\circ} \mathrm{C}$, and with a maximum vapour tension of $1 \mathrm{~atm}$. These conditions were used so as not to increase the powder crystalline status. Thirty samples were prepared at each temperature and at each composition.
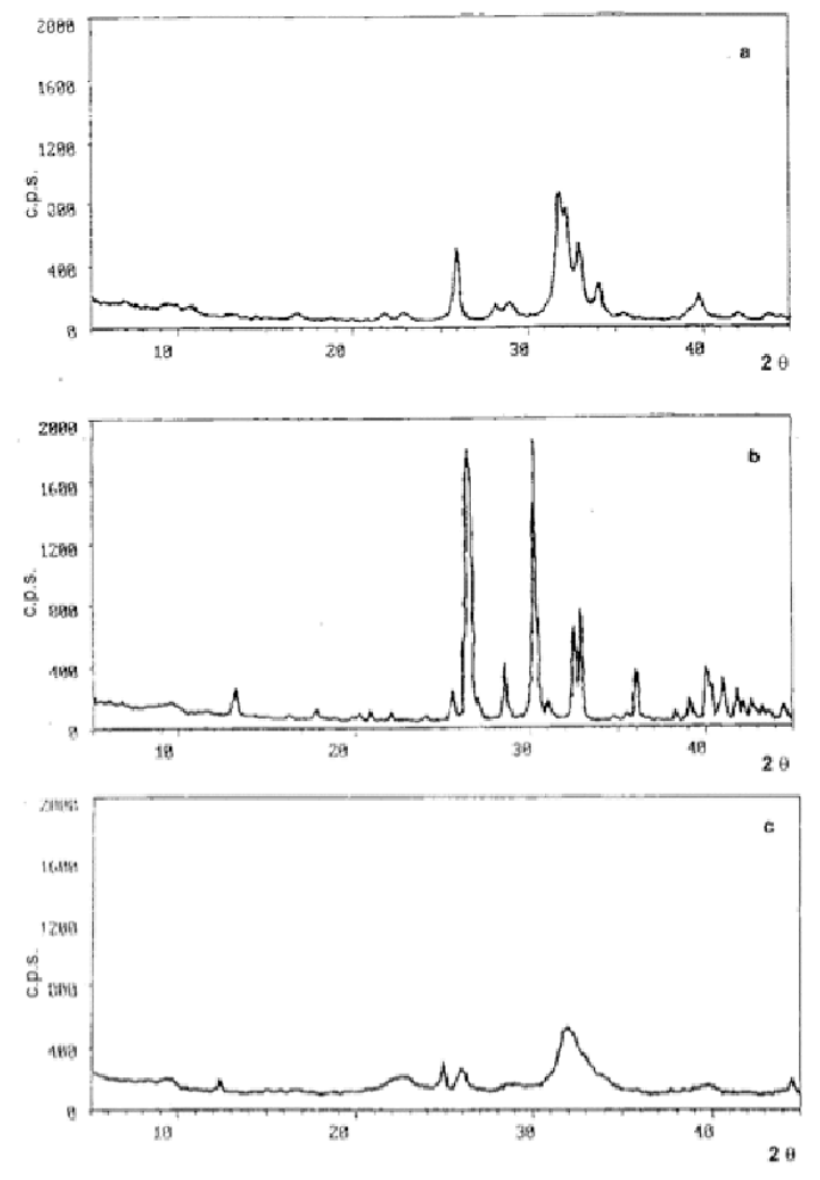

\section{Figure I}

X-ray diffraction patterns of powders; X-ray powder diffraction patterns of: a) commercial hydroxyapatite powder, b) commercial monetite powder, c) compact bovine bone powder.

Bovine bone samples, used as reference, were obtained from the local slaughter-house. The bone was washed with acetone (analytical grade), than manually crashed by means of an iron hammer and homogenized in a stainless steel blender running at full speed (21000 rpm).

\section{Results}

\section{Characterization of calcium phosphate powders}

The powders are characterized by X-ray powder diffraction (Philips model 1730/10) and by scanning electron microscopy (Jeol model JSM-T330) and morphometry. Powder solubility in water at $25^{\circ} \mathrm{C},(72$ hours) has been evaluated by calcium complexonometric quantitative analysis [26].

Two suspensions are prepared by mixing either $30 \mathrm{~g}$ of HAp or $30 \mathrm{~g}$ of $\mathrm{M}$ in $1 \mathrm{l}$ of distilled water. Six more 


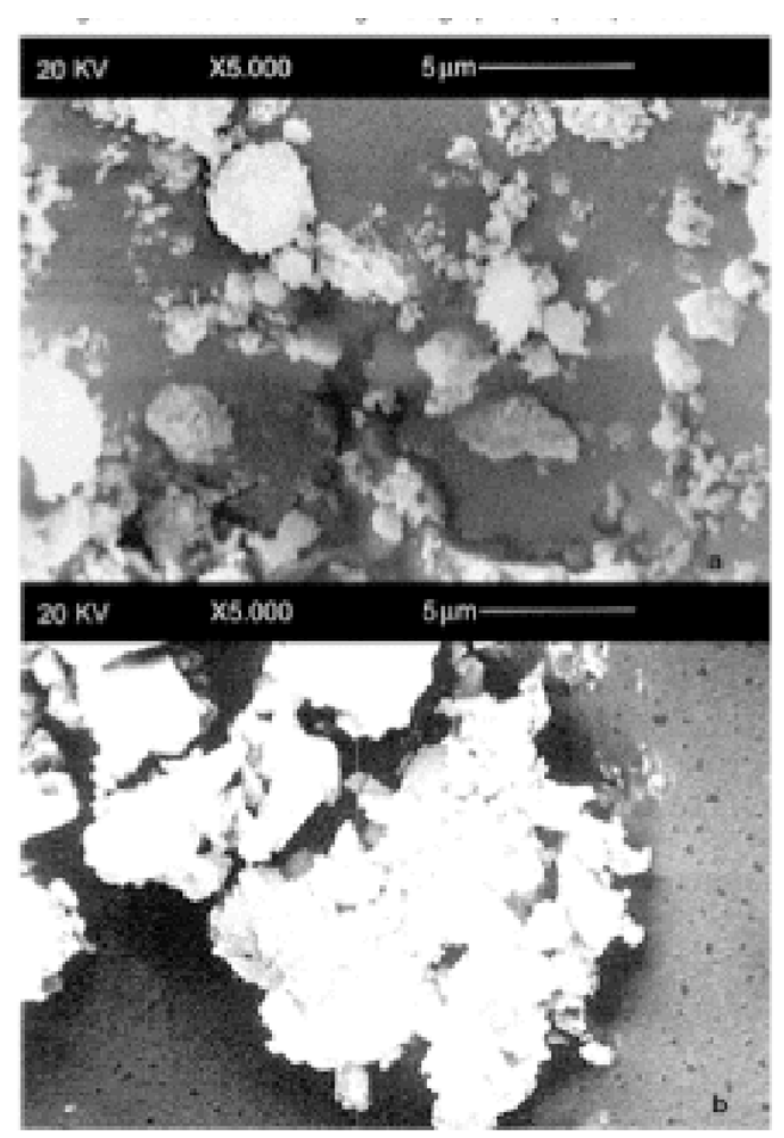

Figure 2

Electron scanning micrographs of pure powders; Electron scanning micrographs of: a) commercial hydroxyapatite powder, b) commercial monetite powder.

mixtures are prepared suspending HAp and $M$ at known weight ratios, $\mathrm{HAp} / \mathrm{M}$ (table 1 ). Water is added to each mixture ( $1 \mathrm{l}$ to $30 \mathrm{~g}$ ), incubated at $25^{\circ} \mathrm{C}$, and the calcium concentrations are determined at 3, 6, 12, 24, 48 and 72 hours, by the complexonometric method [26].

The XRD traces for the hydroxyapatite and monetite powders are presented in figure $(1 \mathrm{a}, 1 \mathrm{~b})$. Each peak is compared with those of pure hydroxyapatite and monetite by ASTM standards [27]. Also shown, in figure 1c, is the X-ray diffraction pattern of bovine bone, showing its low cristallinity.

Morphometric and statistical analisys, of scanning electron microscopy studies (figure 2a) shows that the hydroxyapatite powder is constituted of grains between 1 and 7 micron diameter. The grains (figure 3a) that are 12 microns diameter, represent $65.8 \%$ of the total, those
Table I: Composition of Hap/M mixtures.

\begin{tabular}{ccc}
\hline $\begin{array}{c}\text { Mixtures } \\
\text { names }\end{array}$ & $\begin{array}{l}\text { Composititon (\% in weight } \\
\text { of hydroxyapatie and } \\
\text { moneite) }\end{array}$ & $\begin{array}{l}\text { Hydroxyapatitel } \\
\text { Monetite (moles } \\
\text { ratios) }\end{array}$ \\
\hline a & Hap 100\% & $/$ \\
b & Hap 90\%-M 10\% & $2.4: 1$ \\
c & Hap 80\%-M20\% & $1: 1$ \\
d & Hap 70\%-M30\% & $2: 3$ \\
e & Hap 60\%-M40\% & $2: 5$ \\
f & Hap 50\%-M50\% & $1: 3$ \\
g & Hap 30\%-M70\% & $1: 8$ \\
h & M 100\% & $/$ \\
\hline
\end{tabular}

Composition of the studied HAp/M mixtures and their molar ratios.

that are 2-4 microns are $24.6 \%$ and those between 4 and 7 microns are 9.6\%. Aggregates less than 2 microns are composed of smaller grains that are about $100 \mathrm{~nm}$ in diameter.

Observing monetite powder by scanning electron microscopy (figure 2b), we see that it is composed of three groups of aggregates: the first consists of grains 1-2 microns diameter and constitute $52 \%$ of the total, the second is grains 2-4 microns diameter (29\%), and the third, grains 4-6 microns diameter (19\%) (figure 3b).

The hydroxyapatite and monetite solubilization time courses of the several mixtures at $25^{\circ} \mathrm{C}$ for $72 \mathrm{~h}$ is reported in figure $4 \mathrm{a}$. The calcium concentration from HAp/M suspensions is higher than in both pure HAp and $\mathrm{M}$. The $\mathrm{Ca}^{2+}$ concentration at 72 hours in hydroxyapatite suspension is $0.23 \mathrm{mmoles} / \mathrm{l}$ and in monetite suspension is 0.78 mmoles/l. In mixture (c) (table 1 ) at $72 \mathrm{~h}$, the $\mathrm{Ca}^{2+}$ concentration is 1.51 mmoles/l, and in mixture $(\mathrm{g})$ is 1.61 mmoles/l. The curves in figure 4 a show that the solubility gradually increases over 72 hours reaching a plateau. The $\mathrm{pH}$ values of the several suspensions over the 72 hours are presented in figure $4 \mathrm{~b}$. The values of both the HAp and $\mathrm{M}$ solutions are within the $6.7-7.0 \mathrm{pH}$ range, and those of their mixtures are within 6.0-6.6 pH range. Clearly, the HAp and $M$ powder mixtures with water excess induce chemical reactions such as monetite hydrolysis. Most probably this happens because monetite is the most soluble and acidic compound.

\section{Characterization of manufactured samples}

All of the calcium phosphate samples that we produced were characterized by X-ray powder diffraction (XRD), Vickers hardness test (HV), scanning electron microscopy (SEM), and porosity evaluation. 

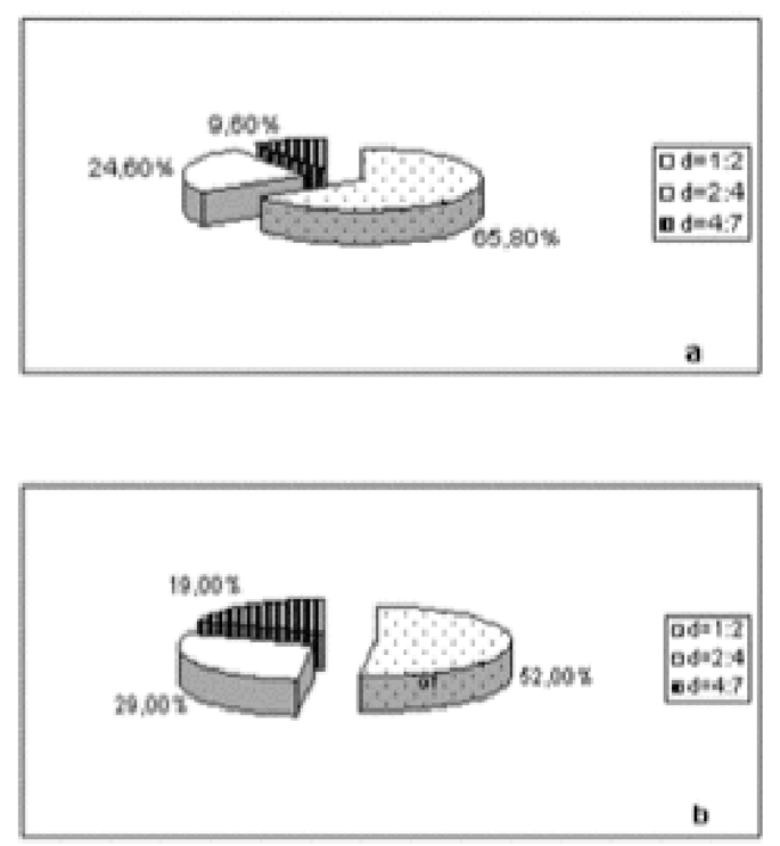

\section{Figure 3}

Frequency distribution of particle dimension in powders; Frequency distribution of particle dimensions of: a) commercial hydroxyapatite powder, b) commercial monetite powder.

Vickers hardness tests (HV) was carried out by Microhardness tester (Type M) Shimadzu (Japan) and the porosity was evaluated by a mercury porosimeter (Porosimeter 2000) Carlo Erba (Italy).

The X-ray diffraction patterns of powders from our samples (e.g. mixtures (a), (h), (f)) show patterns typical of HAp and $M$ powders (figure $1 \mathrm{a}$ and $1 \mathrm{~b}$, figure 5 , respectively). After thermal treatment at temperatures between $37^{\circ} \mathrm{C}$ and $120^{\circ} \mathrm{C}$, neither any new crystal phase formed nor was there an increase of the relative intensity of the peaks (that is a cristallinity increase), for example see in figure 6 the mixtures (h) and (f) at $120^{\circ} \mathrm{C}$, but not the mixture (a) alone.
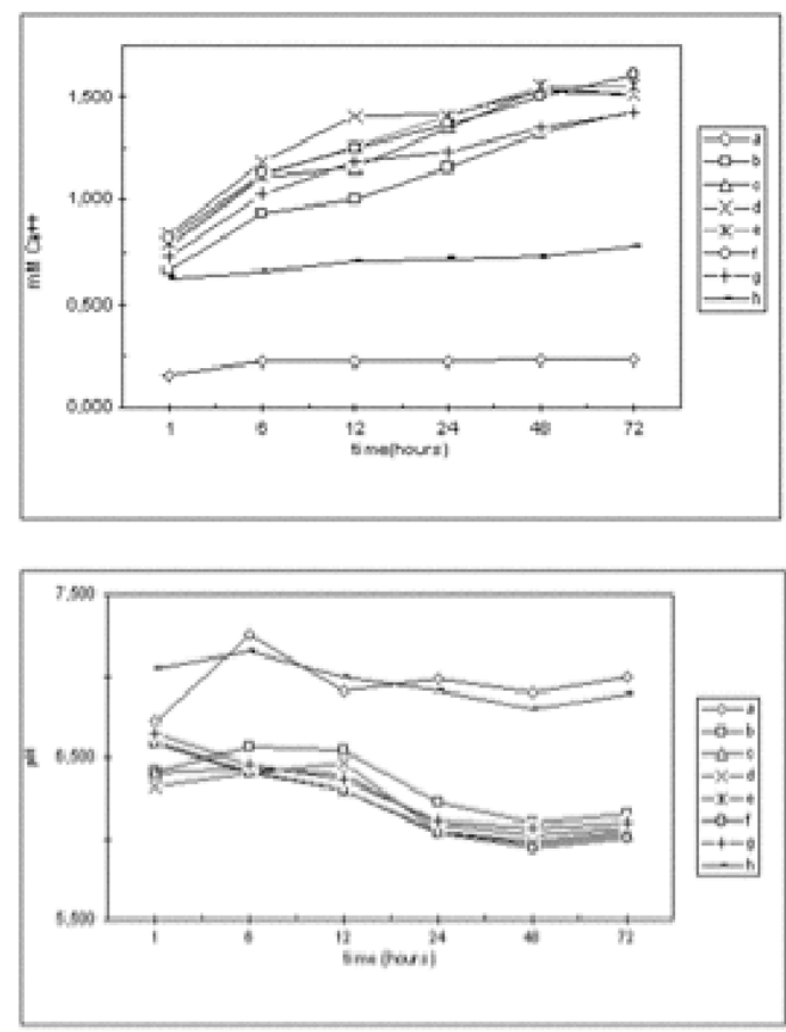

\section{Figure 4}

Calcium concentration and $\mathrm{pH}$ values of the several mixtures; a) Final calcium concentration in water of HAp, M and $\mathrm{HAp} / \mathrm{M}$ mixtures measured within 72 hours from mixing, b) $\mathrm{pH}$ values of $\mathrm{HAp}, \mathrm{M}$ and $\mathrm{HAp} / \mathrm{M}$ mixtures measured within 72 hours from mixing.

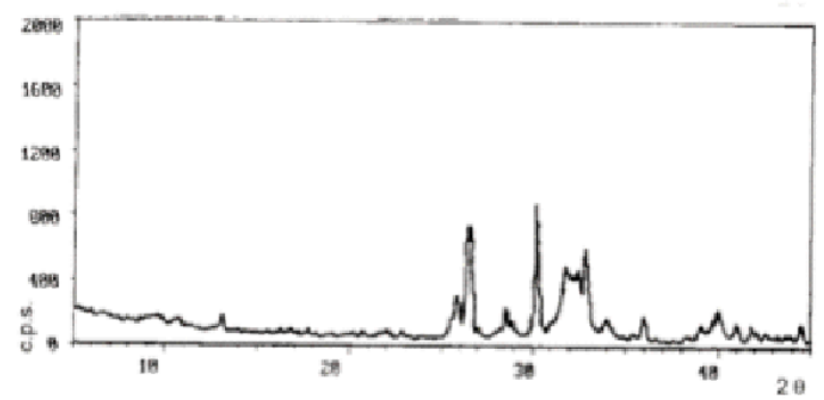

Figure 5

X-ray diffraction pattern of specimen; X-ray powder diffraction patterns of untreated manufactured sample $f$. 
Table 2: HV data (GPa) and standard deviation (SD) of manufacts made by eight mixtures HAp/M treated in a steam satured environment at $37-60-80-100-120^{\circ} \mathrm{C}$.

\begin{tabular}{|c|c|c|c|c|c|c|c|c|c|c|}
\hline \multirow{2}{*}{$\begin{array}{c}\text { MISCEL } \\
\text { A }\end{array}$} & \multicolumn{2}{|c|}{$37^{\circ}$} & \multicolumn{2}{|c|}{$60^{\circ}$} & \multicolumn{2}{|c|}{$80^{\circ}$} & \multicolumn{2}{|c|}{$100^{\circ}$} & \multicolumn{2}{|c|}{$120^{\circ}$} \\
\hline & HV & SD & HV & SD & HV & SD & HV & SD & HV & SD \\
\hline $\mathbf{a}$ & 0.1420 & 0.0158 & 0.1210 & 0.0144 & 0.1020 & 0.0150 & 0.0930 & 0.0186 & 0.1130 & 0,0203 \\
\hline b & 0.1210 & 0.0236 & 0.1450 & 0.0264 & 0.1440 & 0.0178 & 0.1420 & 0.0285 & 0.1570 & 0.0322 \\
\hline c & 0.2150 & 0.0160 & 0.2020 & 0.0308 & 0.2460 & 0.0264 & 0.1970 & 0.0295 & 0.2220 & 0.0362 \\
\hline d & 0.1280 & 0.0107 & 0.1430 & 0.0105 & 0.1550 & 0.0211 & 0.1400 & 0.0080 & 0.1440 & 0.0160 \\
\hline e & 0.1420 & 0.0052 & 0.1190 & 0.0050 & 0.1360 & 0.0184 & 0.1290 & 0.0153 & 0.1760 & 0.0240 \\
\hline $\mathbf{f}$ & 0.2230 & 0.0254 & 0.2180 & 0.0180 & 0.2080 & 0.0479 & 0.1750 & 0.0250 & 0.2360 & 0.0291 \\
\hline $\mathbf{g}$ & 0.1610 & 0.0222 & 0.1530 & 0.0179 & 0.1650 & 0.0135 & 0.1630 & 0.0196 & 0.1780 & 0.0192 \\
\hline h & 0.1290 & 0.0152 & 0.1050 & 0.0195 & 0.1050 & 0.0223 & 0.1400 & 0.0151 & 0.1210 & 0.0291 \\
\hline
\end{tabular}

HV data (GPa) and standard deviations (SD) of manufactured samples made with the mixtures described in table I.
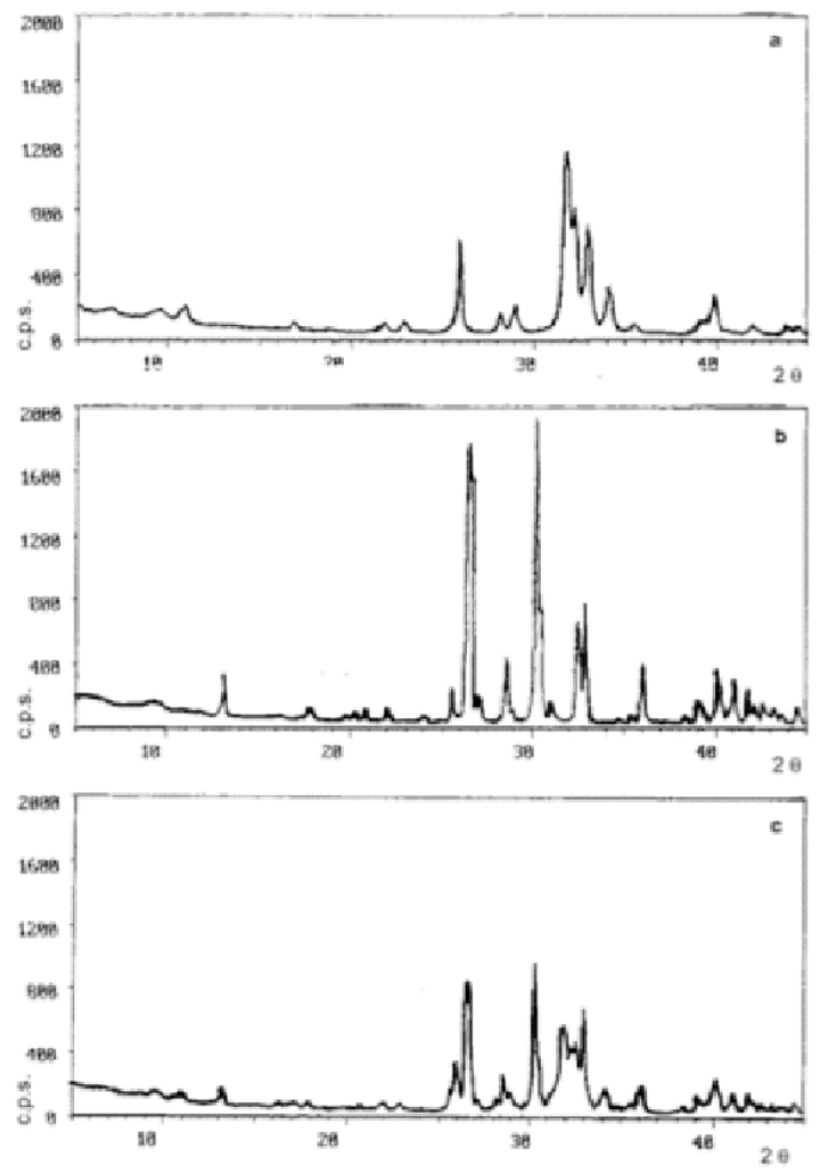

Figure 6

X-ray powder diffraction patterns of specimens; X-ray powder diffraction patterns of samples treated at $120^{\circ} \mathrm{C}$ and produced with: a) hydroxyapatite (sample a), b) monetite (sample b), c) hydroxyapatite/monetite (sample f).



Figure 7

HV data of specimens; HV data of manufactured samples made with the mixtures described in table $I$ at the several treatment temperatures.

Vickers hardness data are reported in table 2 and in figure 7 as the mean of 30 independent determinations for each mixture and each treatment temperature in saturated steam environment, and are expressed as $\mathrm{GPa}$, according to the designation E 92-82 from ASTM standards [28] and SI units. An unpaired Student-t test was performed on the data for the same mixture at different temperatures, and also for the mixtures at each temperature, as shown in table 3 . 
Table 3: Results of unpaired $t$ Student-t test performed on the HV data

\begin{tabular}{|c|c|c|c|c|c|c|c|}
\hline & MI00\% & HAp $30 \%+M 70 \%$ & HAp $50 \%+M 50 \%$ & HAp60\%+M40\% & HAp70\%+M30\% & HAp $80 \%+M 20 \%$ & HAp $90 \%+M 10 \%$ \\
\hline HAp $100 \%$ & $\mathrm{P}<0.01$ & $P<0.005$ & $P<0.0005$ & n.s. & $P<0.005$ & $P<0.0005$ & $P<0.005$ \\
\hline HAP $90 \%+$ MI0\% & n.s. & $p<0.0005$ & $p<0.0005$ & $p<0.005$ & n.s. & $p<0.0005$ & \\
\hline HAp $80 \%+M 20 \%$ & $P<0.0005$ & $p<0.0005$ & $P<0.1$ & $p<0.0005$ & $P<0.0005$ & & \\
\hline HAp70\%+M30\% & n.s. & $p<0.0005$ & $P<0.0005$ & $p<0.0005$ & & & \\
\hline HAp $60 \%+M 40 \%$ & $p<0.005$ & $p<0.0005$ & $p<0.0005$ & & & & \\
\hline HAp $50 \%+M 50 \%$ & $p<0.0005$ & $p<0.0005$ & & & & & \\
\hline \multirow[t]{2}{*}{ HAp30\%+M70\% } & $P<0.0005$ & & & & & & \\
\hline & MI00\% & HАр $30 \%+M 70 \%$ & HAp $50 \%+M 50 \%$ & HAp60\%+M40\% & HAp70\%+M30\% & HAp $80 \%+M 20 \%$ & HAp $90 \%+M 10 \%$ \\
\hline HAp $100 \%$ & $p<0.005$ & $p<0.0005$ & $p<0.0005$ & n.s. & $p<0.0005$ & $\mathrm{p}<0.0005$ & $p<0.0005$ \\
\hline HAp $90 \%+$ MI0\% & $p<0.0005$ & n.s. & $p<0.0005$ & $P<0.0005$ & n.s. & $p<0.0005$ & \\
\hline HAp $80 \%+M 20 \%$ & $p<0.0005$ & $P<0.0005$ & $\mathrm{P}<0.025$ & $p<0.0005$ & $P<0.0005$ & & \\
\hline HAp70\%+M30\% & $P<0.0005$ & $\mathrm{P}<0.025$ & $P<0.0005$ & $P<0.0005$ & & & \\
\hline HAp $60 \%+M 40 \%$ & $p<0.005$ & $\mathrm{p}<0.0005$ & $p<0.0005$ & & & & \\
\hline HAp $50 \%+M 50 \%$ & $p<0.0005$ & $p<0.0005$ & & & & & \\
\hline \multirow[t]{2}{*}{ HAp30\%+M70\% } & $p<0.0005$ & & & & & & \\
\hline & MI00\% & HAp30\%+M70\% & HAp $50 \%+M 50 \%$ & HAp $60 \%+M 40 \%$ & HAp70\%+M30\% & HAp $80 \%+M 20 \%$ & HAp $90 \%+$ MI0\% \\
\hline HAp $100 \%$ & n.s. & $\mathrm{p}<0.0005$ & $p<0.0005$ & $\mathrm{p}<0.0005$ & $p<0.0005$ & $\mathrm{p}<0.0005$ & $\mathrm{p}<0.0005$ \\
\hline HAp $90 \%+$ MI0\% & $P<0.0005$ & $P<0.0005$ & $P<0.0005$ & $p<0.1$ & $P<0.05$ & $P<0.0005$ & \\
\hline HAp $80 \%+M 20 \%$ & $p<0.0005$ & $p<0.0005$ & $p<0.005$ & $P<0.0005$ & $P<0.0005$ & & \\
\hline HAp70\%+M30\% & $p<0.0005$ & $p<0.005$ & $p<0.0005$ & $p<0.005$ & & & \\
\hline HAp $60 \%+M 40 \%$ & $P<0.0005$ & $\mathrm{p}<0.0005$ & $P<0.0005$ & & & & \\
\hline HAp $50 \%+M 50 \%$ & $P<0.0005$ & $p<0.0005$ & & & & & \\
\hline \multirow[t]{2}{*}{ HAp30\%+M70\% } & $\mathrm{P}<0.0005$ & & & & & & \\
\hline & MI00\% & HAp $30 \%+M 70 \%$ & HAp $50 \%+M 50 \%$ & HAp $60 \%+M 40 \%$ & HAp70\%+M30\% & HAp $80 \%+M 20 \%$ & HAp $90 \%+$ MI0\% \\
\hline HAp $100 \%$ & $P<0.0005$ & $\mathrm{p}<0.0005$ & $p<0.0005$ & $\mathrm{p}<0.0005$ & $p<0.0005$ & $\mathrm{p}<0.0005$ & $p<0.0005$ \\
\hline HAp $90 \%+$ MI0\% & n.s. & $\mathrm{P}<0.1$ & $p<0.0005$ & $p<0.025$ & n.s. & $p<0.0005$ & \\
\hline HAp $80 \%+M 20 \%$ & $P<0.0005$ & $p<0.0005$ & $p<0.01$ & $p<0.0005$ & $P<0.0005$ & & \\
\hline HAp70\%+M30\% & n.s. & $p<0.0005$ & $P<0.0005$ & $P<0.005$ & & & \\
\hline HAp $60 \%+M 40 \%$ & $p<0.025$ & $p<0.0005$ & $p<0.0005$ & & & & \\
\hline HAp $50 \%+M 50 \%$ & $p<0.0005$ & $p<0.05$ & & & & & \\
\hline \multirow[t]{2}{*}{ HAp30\%+M70\% } & $p<0.0005$ & & & & & & \\
\hline & MI00\% & HAp30\%+M70\% & HAp $50 \%+M 50 \%$ & HAp $60 \%+M 40 \%$ & HAp70\%+M30\% & HAp $80 \%+M 20 \%$ & HAp $90 \%+$ MI0\% \\
\hline HAp $100 \%$ & n.s. & $p<0.0005$ & $p<0.0005$ & $p<0.0005$ & $p<0.0005$ & $p<0.0005$ & $p<0.0005$ \\
\hline HАр $90 \%+M 10 \%$ & $P<0.0005$ & $p<0.01$ & $P<0.0005$ & $\mathrm{P}<0.025$ & $p<0.1$ & $P<0.0005$ & \\
\hline HAp $80 \%+M 20 \%$ & $p<0.0005$ & $p<0.0005$ & $\mathrm{P}<0.1$ & $p<0.0005$ & $P<0.0005$ & & \\
\hline HAp70\%+M30\% & $P<0.0005$ & $P<0.005$ & $P<0.0005$ & $p<0.0005$ & & & \\
\hline HAp $60 \%+M 40 \%$ & $P<0.0005$ & n.s. & $P<0.0005$ & & & & \\
\hline HAp $50 \%+M 50 \%$ & $p<0.0005$ & $p<0.0005$ & & & & & \\
\hline HAp30\%+M70\% & $p<0.0005$ & & & & & & \\
\hline
\end{tabular}

Results of unpaired $t$ Student- $t$ test performed on the $H V$ data obtained from manufactured samples prepared with different mixtures and treated at each temperature.

There was no relationship found between HV and treatment temperature of the mixtures. Much more significant is the relationship of $\mathrm{HV}$ with mixture composition, and only in two of the samples is HV higher than in the other mixtures. That is the specimens with HAp/M mixtures (c) and (f), that have HV values within the $0.20-0.25 \mathrm{GPa}$ range. $\mathrm{HV}$ values of specimens obtained with HAp have a mean value of $0.11 \mathrm{GPa}$, those from $\mathrm{M}$ have a mean value of $0.10 \mathrm{GPa}$.

The total porosity, as determined by mercury porosimeter, in samples (c) and (f) decreases in the range of 50-60\%,
Table 4: Porosity percentage of specimens

\begin{tabular}{ccccc}
\hline Samples & untreated & $\mathbf{3 7 ^ { \circ } \mathbf { C }}$ & $\mathbf{6 0 ^ { \circ } \mathbf { C }}$ & $120^{\circ} \mathbf{C}$ \\
\hline a & 67.45 & 71.78 & 59.36 & 50.14 \\
c & 59.35 & 50.63 & 49.02 & 52.55 \\
f & 61.44 & 41.36 & 37.21 & 48.67
\end{tabular}

Porosity percentage of a, c, f manufactured samples (see Table I) at the described temperatures. 
Pore distribution analysis of the (c) and (f) samples after thermal treatment shows three groups by pore sizes. They are characterized by pores $0.004-0.07$ microns in diameter, 0.07-0.4 microns and 4-7 microns (about 1\%). Figure 8 shows the pore distribution analysis of sample (f) thermally untreated (figure 8a), and treated at $60^{\circ} \mathrm{C}$ (figure $8 \mathrm{~b}$ ). By comparison, a sample of compact bovine bone shows both $0.01-0.1$ micron and $0.6-6$ micron pores (figure $8 \mathrm{c}$ ).

Scanning electron microscopy of the surfaces of specimens (c) and (f) (figures 9a,9b) show a cohesion of the powders grains. Here (c) is more compact in comparison to (f), despite the presence of small pores. Observing the fracture surfaces of samples (c) and (f) we see long crystals of monetite with small grains of the hydroyapatite above them (figures 10a,10b). In the (c) sample the monetite crystals are spaced further apart, in the (f) sample the monetite crystals overlap each other.

\section{Discussion}

As described in the section above, all tested HAp/M powders mixtures were more soluble in water than those of pure compounds. According to these data, we assumed that in samples made from HAp/M mixtures, a partial solubilization of the chemicals occurs. This process should be useful to enhance the mixing of the reactants and the production of fillers composed of newly formed HAp crystals in the microspaces among the grains, and to obtain an higher coherence in manufactured samples.

The results described demonstrate the complexity of the systems, even those with heterogeneous compositions and prepared with constant parameters such as temperature. To interpret the phenomena that occur in the processes that compact these specimens, it is useful to consider that these processes occur within micropores [29]. In such microspaces, many processes occur at grain and micropore interfaces, which probably contain an oversaturated environment.

The manufactured samples are treated at temperatures between $37^{\circ}$ and $120^{\circ} \mathrm{C}$ in a steam saturated environment to allow powders to solubilize without alteration of their crystallinity. Calcium phosphates are then precipitated into the grain interfaces without increasing HAp and $\mathrm{M}$ crystallinity, as demonstrated by X-ray diffraction studies of pure compounds. The thermal process always determines an higher coherence in the products [30,31]. This hypothesis is supported by the porosity \% results, which decrease with thermal treatment, even if slightly, in samples (c) and (f), (table 4).

In $\mathrm{HAp} / \mathrm{M}$ samples, the solubilization and reprecipitation processes are accelerated, $\mathrm{Ca}^{2+}$ and $\mathrm{HPO}_{4}{ }^{2+}$ ion concentra-
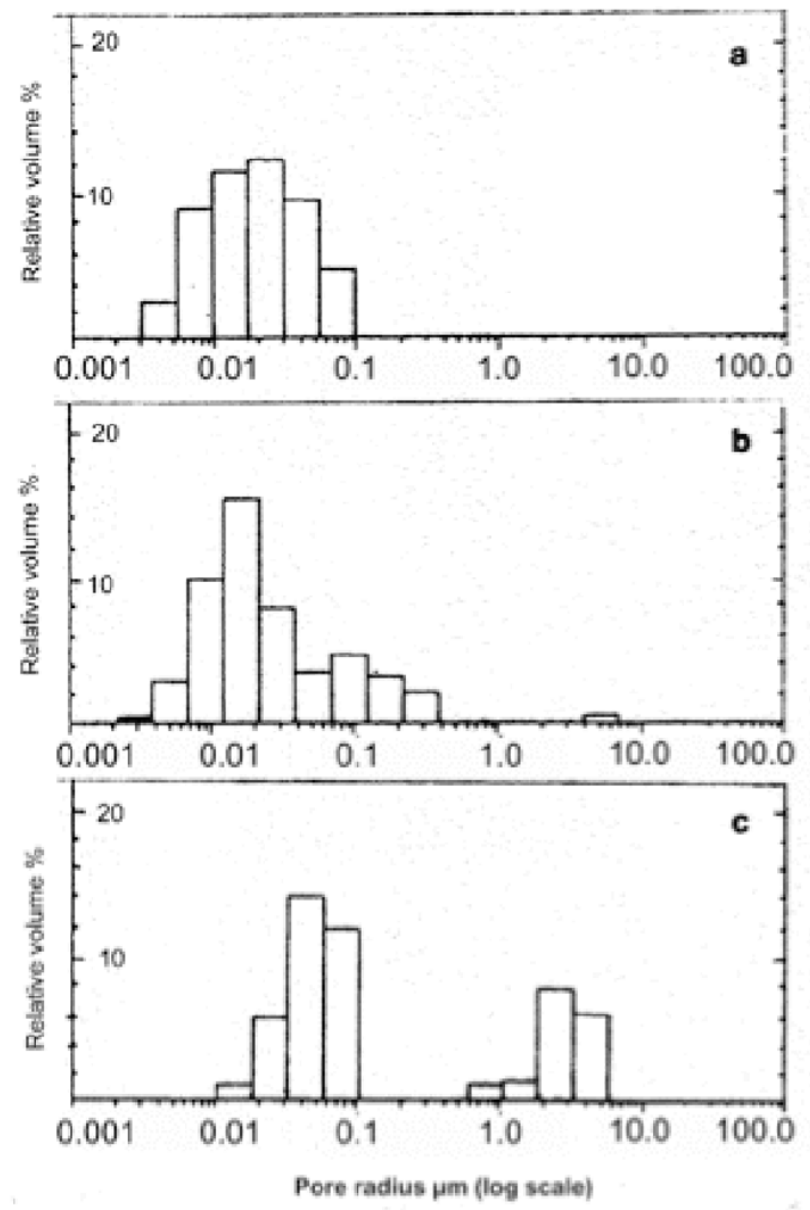

\section{Figure 8}

Distribution of pore volume in percentage; Relative volume percentage distribution of pores in function of pore radiuses: a) sample f untreated, b) sample f treated at $60^{\circ} \mathrm{C}$, c) sample of compact bovine bone.

tions increase and then the ions are precipitated as HAp. Moreover, we should consider solubility of the initial inorganic components, and the formation of hydrolysis products (also at supersaturation, near the interfaces). They could precipitate by nucleation on grain surfaces (figures 10a,10b), producing intermediates with several solubility products. It is also useful to consider mechanical tests that show that temperature and vapour tension gradients can occur throughout the specimen thickness (table 2, figure 7). It is useful to note that standard treatment procedures do not necessarily give the same hardening with cement-like reaction within the several shapes and volumes of the samples. Scanning electron microscopy images of both external and fracture surfaces (that is external and internal surfaces) (figures $9 a, 9 b$ and 


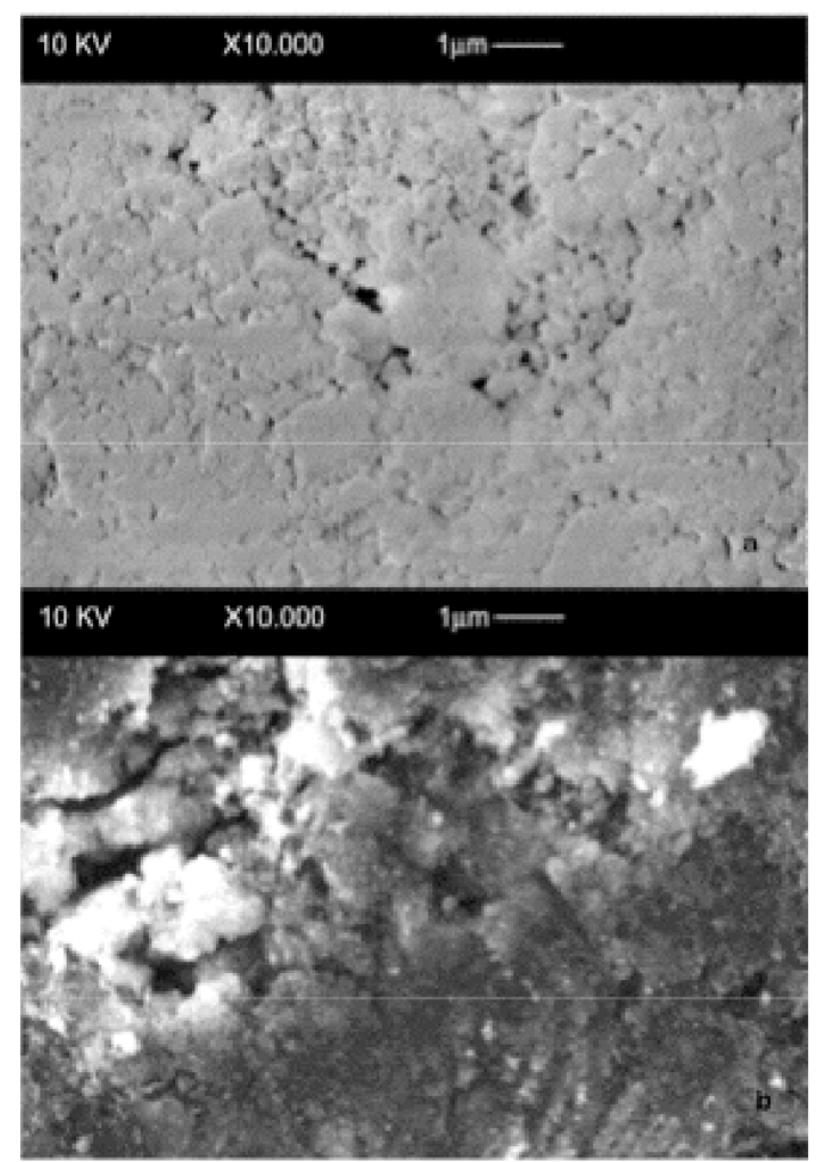

Figure 9

Electron scanning micrographs of external surface of specimens; a) External surface by scanning electron micrographs of type c (table I) manufactured sample. b) External surface by scanning electron micrographs of type $f$ (table I) manufactured sample.

$10 \mathrm{a}, 10 \mathrm{~b})$ of the samples show different coherence of the grains, some times with several crystals distributions between the external surfaces and the interior regions of the specimens. Hydroxyapatite is fragile, based on its low reactivity in freshly distilled water, (i.e., $\mathrm{pH}=7$ ), so that its grains do not sufficiently set to give mechanical consistency to the specimen.

Samples of (c) and (f) mixtures show the highest HV values (0.20-0.25 GPa). These results demonstrate that the HAp to $M$ stoichiometric ratios (1:1 and 1: 3 ) optimize the solubilization-reprecipitation process at grain interfaces.

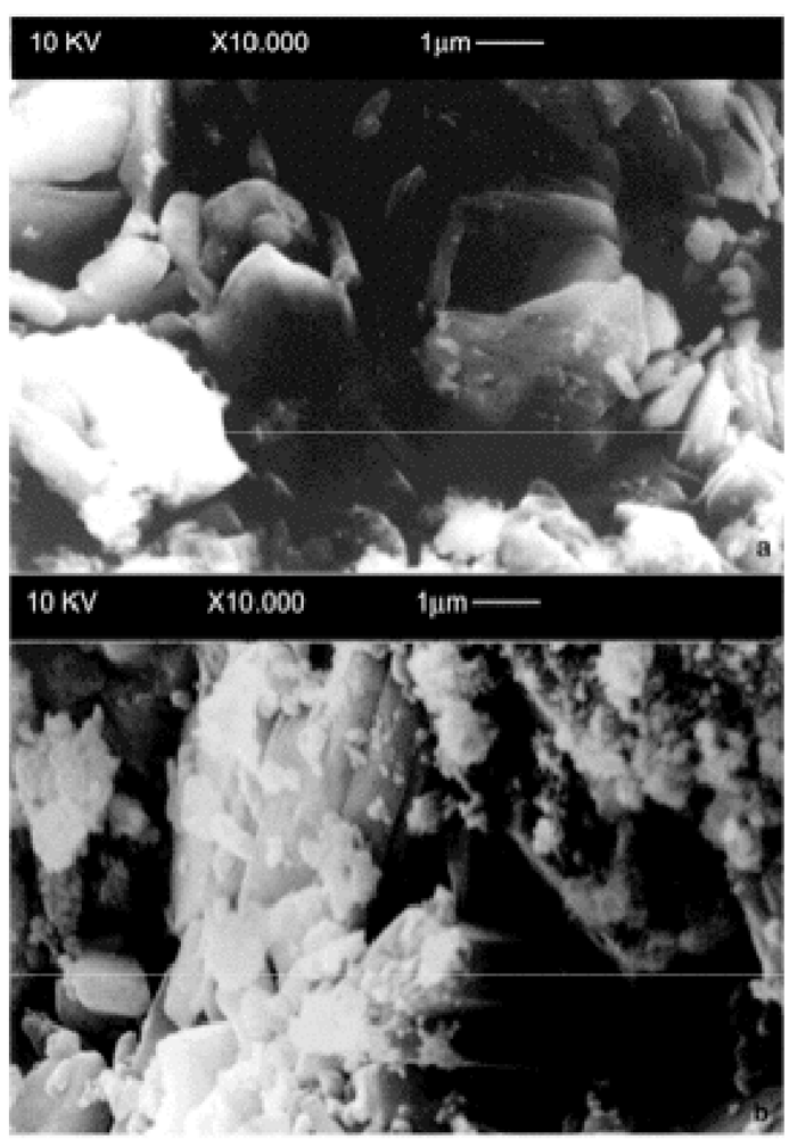

Figure 10

Electron scanning micrographs of fracture surfaces of specimens; a) Fracture surface by scanning electron micrographs of type c (table I) manufactured sample. b) Fracture surface by scanning electron micrographs of type $f$ (table I) manufactured sample.

To compare with our results from the fillers and cements tested, we used a specimen of bovine compact bone with the same instrument and the same experimental conditions, and determined the mean HV value of $0.42 \mathrm{GPa}$. The morphology of sample (c) by scanning electron microscopy of the fractured surface is shown in figures 9a and 10a. Samples (c) and (f) show three groups by pore size, whereas a specimen of compact bovine bone show 10-100 nm pore size and 0.6-5 micron macropores. On the basis of the previous discussion of hydroxyapatite and monetite specimens, we obtained samples with mechanical properties useful to apply as either cements or fillers at mild temperature and pressure conditions. Such products can be further enhanced by the use of other inorganic 
components the bone, and can easily be reabsorbed and repopulated by the surrounding bone tissue.

\section{Conclusions}

In summary, based on our experimental data, we conclude that a solubilization-reprecipitation process occur, which is more intensive in specimens of $80 \%$ hydroxyapatite (HAp) with $20 \%$ monetite (M) (c), and of 50\% HAp with $50 \% \mathrm{M}$ (f), as demonstrated by Vickers hardness data. The manufacturing process is carried out at low temperature and in a steam saturated environment to obtain more consistent materials, without altering powders crystallinity. These HAp/M samples show pore dimension distribution, which is useful to cellular repopulation if implanted in living tissues.

\section{Authors' contributions}

Calafiori Anna Rita: Manufactured samples preparations, calcium solubility tests, HV and porosity determinations of manufactured samples;

Marotta M.: Scanning electron microscopy micrographs and their evaluation;

Nastro A.: Acquisition and evaluation of X-ray diffractions and their evaluation;

\section{Martino G.: Director of research.}

\section{Acknowledgements}

The research was supported by funds fom Italian Ministry of Public Education (MIUR) and Multifund Operative Program (P.O.P.) of E.C.

The authors thank Prof. R. Aiello, Full Professor - Department of Chemical Engineering and of New Materials-Unical, for his helpfull discussions and encouragments to acquire deep knowledge in the field of cements and for the availability of instruments in his laboratory.

\section{References}

I. Daculsi G, Passutí N, Martin S, Deudon S, LeGeros RE, Rather S: Macroporous calcium phosphate ceramic for long bone surgery in humans and dogs. Clinical and histological study. Biomed Mater Res 1990, 24(3):379-396.

2. Yamagushi K, Hirano T, Yoshida G, Iwasaki K: Degradation-resistant character of synthetic hydroxyapatite blocks filled in bone defects. Biomaterials 1995, I 6(13):983-985.

3. Suh H, Lee $\mathrm{C}$ : Biodegradable ceramic-collagen composite implanted in rabbit tibiae. Asaio J 1995, 4I(3):M652-656.

4. Jarcho $M$ : Retrospective analysis of hydroxyapatite development for oral implant applications. Dent Clin North Am 1992, 36(I): $19-26$

5. Capanna R, Manfrini M, Tigani D, Giunti A: Tricalcium phosphate and hydroxyapatite ceramics in the surgery of bone tumors: preliminary results. Chir Organi Mov 1991, 76(3):245-254

6. Kamerer DB, Hirsch BE, Snyderman CH, Costantino P, Friedman CD: Hydroxyapatite cement: a new method for achieving watertight closure in transtemporal surgery. Am J Otol 1994 I 5(I):47-49.

7. Costantino PD, Friedman CD, Jones K, Chow LC, Sisson GA: Experimental hydroxyapatite cement cranioplasty. Plast Reconstr Surg 1992, 90(2): 174-185.

8. Costantino PD, Friedman CD, Jones K, Chow LC, Pélzer HJ, Sisson GA: Hydroxyapatite cement I. Basic chemistry and histologic properties. Arch Otolaryngology Head Neck Surg 1991, I I 7(4):379-384.

9. Friedman CD, Costantino PD, Jones K, Chow LC, Pelzer HJ, Sisson GA: Hydroxyapatite cement. II. Obliteration and reconstruction of the cat frontal sinus. Arch Otolaryngology-HeadNeck-Surg |991, I I 7(4):385-899.

10. Rosen HM, Ackerman JL: Porous block hydroxyapatite in orthognatic surgery. Angle Orthod 1991, 61(3): I85-I91.

II. Reddi SP, Stevens MR, Kline SN, Villanueva P: Hydroxyapatite cement in craniofacial trauma surgery: indications and early experience. J Craniomaxillofac Trauma 1999, 5(I):7-12.

12. Daculsi G, Weiss P, Bouler JM, Gauthier O, Millot F, Aguado E: Biphasic calcium phosphate/hydrosoluble polymer composites: a new concept for bone and dental substitution biomaterials. Bone I999, 25(2Suppl):59S-6IS.

13. Okada Y, Kobayashi M, Neo M, Kokubo T, Nakamura T: Ultrastructure of the interface between bioactive composite and bone: comparison of apatite and wollastonite containing glassceramic filler with hydroxyapatite and beta-tricalcium phosphate fillers. I Biomed Mater Res 200I, 57(I): I0I-I07.

14. Comuzzi L, Ooms E, Jansen JA: Injectable calcium phosphate cement as a filler for bone defects around oral implants: an experimental study in goats. Clin Oral Implants Res 2002, I3(3):304-3 | I

I5. Yuan H, Yang Z, de Bruijn JD, Li Y, de Groot K, Zhang X: Materialdependent bone induction by calcium phosphate ceramics: a 2.5-year study in the dog. Biomaterials 200I, 22(19):26I7-2623.

16. Guigui P, Hardouin P: Histologic and biomechanic evaluation of posterolateral arthrodesis using a biphasic ceramic of calcium phosphate as bone substitute. Experimental study with sheep. Bull Acad Natl Med 2000, I 84(2):403-4I 2.

17. Du C, Cui FZ, Zhang W, Feng QL, Zhu XD, de Groot K: Formation of calcium phosphate/collagen composites through mineralization of collagen matrix. I Biomed Mater Res 2000, 50(4):518-527.

18. Vicente V, Meseguer L, Martinez F, Galian A, Rodriguez J, Alcaraz M, Clavel $M$ : Ultrastructural study of the osteointegration of bioceramics (whitlockite and composite beta-TCP+collagen) in rabbit bone. Ultrastruct Pathol 1996, 20(2): I79-188.

19. Heymann D, Delecrin J, Deschamps C, Gouin F, Padrines M, Passuti $\mathrm{N}$ : In vitro assessment of combining osteogenic cells with macroporous calcium-phosphate ceramics. Rev Chir Orthop Reparatrice Appar Mot 200I, 87(I):8-I7.

20. Toquet J, Rohanizadeh R, Guicheux J, Couillaud S, Passuti N, Daculsi $\mathrm{G}$, Heymann D: Osteogenic potential in vitro of human bone marrow cells cultured on macroporous biphasic calcium phosphate ceramic. J Biomed Mater Res 1999, 44(I):98-108.

21. Fukase $Y$, Wada S, Uehara H, Terakado M, Sato H, Nishiyama $M$ : Basic studies on hydroxyapatite cement: I. Setting reaction. J Oral Sci 1998, 40(2):71-76.

22. Fernandez E, Gil FJ, Best S, Ginebra MP, Driessens FC, Planell JA: The cement setting reaction in the CaHPO4-alpha-Ca3(PO4)2 system: an X-ray diffraction study. J Biomed Mater Res 1998 , 42(3):403-406.

23. Kurashina K, Kurita H, Totani A, Kobayashi S, Kyoshima K, Hirano M: Experimental cranioplasty and skeletal augmentation using an alpha-tricalcium phosphate/dicalcium phosphate dibasic/ tetracalcium phosphate monoxide cement: a preliminary short-term experiment in rabbits. Biomaterials 1998, I9(79):701-706.

24. Kurashina K, Kurita H, Hirano M, Totani A, Klein CP, de Groot K: In vivo study of calcium phosphate cements: implantation of on alpha-tricalcium dicalcium phosphate dibasic/tetracalcium phosphate monoxide cement paste. Biomaterials 1997 , I 8(7):539-543.

25. Frayssinet $\mathrm{P}$, Mathon D, Lerch A, Autefage A, Collard P, Roquet N: Osseointegration of composite calcium phosphate bioceramics. J Biomed Mater Res 2000, 50(2): I 25-30.

26. IM Kolthoff: Determinazioni complessometriche. Chimica Analit ica quantitativa Padova, Piccin; 2004.

27. International Centre for Diffraction Data: Power Diffraction File Search Manual (I 987): records $n^{\circ}$ 9-432- $n^{\circ}$ 9-80.

28. "Standard test method for Vickers Hardness of metallic materials" in ASTM, designation E 92-82 (reapproved 1992). 
29. Katsura N: Nanospace theory for biomineralization. Dentistry in Japan 1990, 27:57-63.

30. Liu C, Shen W, Gu Y, Hu L: Mechanism of the hardening process for a hydroxyapatite cement. J Biomed Mater Res 1997, 35(1):75-80.

31. Ginebra MP, Fernandez E, De Maeyer EA, Verbeeck RM, Boltong MG, Ginebra J, Driessens FC, Planell JA: Setting reaction and hardening of an apatitic calcium phosphate cement. J Dent Res 1997, 76(4):905-912.

Publish with Bio Med Central and every scientist can read your work free of charge

"BioMed Central will be the most significant development for disseminating the results of biomedical research in our lifetime. " Sir Paul Nurse, Cancer Research UK

Your research papers will be:

- available free of charge to the entire biomedical community

- peer reviewed and published immediately upon acceptance

- cited in PubMed and archived on PubMed Central

- yours - you keep the copyright

Submit your manuscript here:

http://www.biomedcentral.com/info/publishing_adv.asp
BioMedcentral 